\title{
Discurso de ódio na tribuna da Câmara dos Deputados
}

\author{
Deysi Cioccari \\ Vanderlei de Castro Ezequiel
}

Resumo: Este trabalho analisa a presença do discurso de ódio na cena política brasileira contemporânea. Além da abordagem conceitual do tema, o trabalho apresenta um caso concreto de discurso de ódio. A principal orientação teórico-metodológica deste trabalho é a Análise de Discurso de linha francesa, entendendo o discurso político (Charaudeau) como enunciação de uma época. As teses da Sociedade do Espetáculo (Debord) conduzem a análise crítica do corpus. Concluiu-se que o discurso de ódio na cena política contemporânea expressa íntima relação com a espetacularização da política.

Palavras-chave: Discurso de ódio. Liberdade de expressão. Espetacularização.

\section{Hate speech in the tribune of the Brazilian Chamber of Deputies}

Abstract: This paper analyzes the presence of hate speech in contemporary Brazilian politics. In addition to the conceptual approach of the theme, the paper presents a concrete case of hate speech. The main theoretical-methodological orientation of this work is the Discourse Analysis of French line, understanding the political discourse (Charaudeau) as enunciation of an epoch. The Theses of the Society of the Spectacle (Debord) lead the critical analysis of the corpus. It was concluded that the hate speech on the contemporary political scene expresses close relation with the spectacularization of politics.

Keywords: Hate speech. Freedom of expression. Spectacularization. 


\section{Introdução}

Nos últimos anos, a sociedade brasileira tem presenciado episódios de violência e manifestações de intolerância à opinião divergente. Prega-se abertamente o extermínio da vida dos antagonistas políticos, numa clara manifestação de ideais fascistas.

Entende-se que a democracia é o sistema que pressupõe o dissenso, isto é, que a ordem democrática subentende o equilíbrio no conflito. Porém, para existir a democracia é preciso que haja respeito à singularidade e aos direitos fundamentais que as instituições e cidadãos devem ao outro com quem coexistem. Dessa forma, a essência da democracia é, portanto, a aceitação da pluralidade, que implica a coexistência pacífica das diferenças.

Outro pilar da democracia, a liberdade de expressão é um direito imprescindível, garantindo o trânsito de opiniões pelo espaço público. Trata-se de um direito inalienável de todo e qualquer indivíduo de manifestar seu pensamento sem censura, conforme estabelecido

pelo artigo $5^{\circ}$ da Constituição Federal Brasileira. É, por isso, componente essencial das sociedades democráticas, que têm na igualdade e na liberdade seus pilares.

No entanto, a liberdade de expressão não é absoluta, e não pode ser invocada para a prática de intolerância e preconceito de qualquer ordem. Também não deve ser base para a defesa do uso de expressões que caracterizam postura criminosa como a difamação e a injúria, a calúnia ou a incitação a qualquer forma de violência.

O objetivo deste trabalho é analisar o discurso de ódio presente na cena política brasileira contemporânea. A principal orientação teórico-metodológica é a Análise de Discurso. O trabalho inicia com uma fundamentação teórica sobre o discurso de ódio e segue com um breve debate sobre liberdade de expressão. Em seguida apresenta o corpus contendo o discurso de ódio presente numa manifestação do deputado federal Jair Bolsonaro na tribuna da Câmara de Deputados. Finaliza com uma análise crítica sobre a espetacularização da política.

\section{Discurso de ódio}

De modo geral, o discurso de ódio - tradução do termo em inglês: hate speech - é aquele discurso que promove o ódio e incita a discriminação, hostilidade e violência. Refere-se a qualquer ato de comunicação que diminua, inferiorize uma pessoa, empregando aspectos passíveis de discriminação tais como: gênero, raça, religião, nacionalidade, orientação sexual, 
entre outros. Além disso, o discurso de ódio também é empregado para perseguir, insultar e justificar a privação dos direitos humanos podendo, em casos extremos, dar razão a homicídios e genocídios como o holocausto na Alemanha nazista. De acordo com Silva et al. (2011, p. 447):

O discurso de ódio compõe-se de dois elementos básicos: discriminação e externalidade. É uma manifestação segregacionista, baseada na dicotomia superior (emissor) e inferior (atingido) e, como manifestação que é, passa a existir quando é dada a conhecer por outrem que não o próprio autor. A fim de formar um conceito satisfatório, devem ser aprofundados esses dois aspectos, começando pela externalidade.

Assim como qualquer expressão discursiva, o discurso de ódio exige a concretização das ideias, isto é, sair do plano mental para o plano fático. Quando não é externado o discurso é apenas pensamento, emoção, não causando qualquer dano a quem porventura seja alvo. $\mathrm{O}$ problema surge quando o pensamento é externado, cedendo lugar à presença da palavra. Assim, o discurso ganha existência concreta e torna-se disponível àqueles a quem visa denegrir e também àqueles a quem intenciona incitar contra os denegridos. Concretizado, o discurso realiza seus efeitos nocivos, destacando: ataque à dignidade alheia e violações a direitos fundamentais. Em suma, manifestado publicamente, o discurso do ódio causa o dano.

No âmbito do direito, o discurso de ódio é qualquer discurso, conduta ou gesto, falado, escrito ou representado que possa incitar violência ou externar ação discriminatória contra outrem ou, ainda, ofender ou intimidar pessoas. Existe um consenso internacional sobre a necessidade de proibição do discurso de ódio, considerando-se também que essa proibição não pode ferir o princípio de liberdade de expressão, essencial para a manutenção da democracia.

O discurso de ódio também pode ser dividido em dois atos: o insulto e a instigação. $\mathrm{O}$ primeiro refere-se diretamente à vítima, ou seja, a agressão a uma pessoa ou grupo de pessoas que partilham de determinado traço. Enquanto o segundo ato direciona-se a terceiros, não identificados com as vítimas, que são convocados para reforçar o grupo dos agressores, não apenas no discurso, mas também com ações.

Em sua estratégia de persuasão, o discurso de ódio utiliza instrumentos e técnicas da área de publicidade e propaganda para obter adeptos, dentre as quais: a criação de estereótipos, a substituição de nomes, a seleção exclusiva de fatos favoráveis ao seu ponto de vista, a criação de "inimigos", o apelo à autoridade e a afirmação e repetição (BROWN apud SILVA et al., 
2011, p. 448). Outra estratégia utilizada para aumentar a probabilidade de aceitação desse discurso é a utilização de argumentos emocionais.

\begin{abstract}
Quando uma pessoa dirige um discurso de ódio a outra, a dignidade é vulnerada em sua dimensão intersubjetiva, no respeito que cada ser humano deve ao outro. Mas não só isso. No caso do discurso odiento, vai-se além: é atacada a dignidade de todo um grupo social, não apenas a de um indivíduo. Mesmo que este indivíduo tenha sido diretamente atingido, aqueles que compartilham a característica ensejadora da discriminação, ao entrarem em contato com o discurso odiento, compartilham a situação de violação. Produz-se o que se chama de vitimização difusa (SILVA et al., 2011, p. 449).
\end{abstract}

Os indivíduos ou grupos atingidos pelo discurso do ódio são, invariavelmente, sujeitos em condições de vulnerabilidade, reconhecidos como pertencentes ao grupo não dominante.

\title{
Um debate importante
}

O pesquisador neozelandês, Jeremy Waldron, define "hate speech" como "publicações que expressam profundo desrespeito, ódio e difamação contra membros de grupos minoritários" (WALDRON, 2012, p. 27) ${ }^{1}$. Para o pesquisador, ódio é uma emoção de desprezo, intolerância de aversão extrema. Neste sentido, o discurso de ódio é aquele que expressa, incita, provoca ou apoia o ódio contra determinado grupo de indivíduos ou coletividade, distinguidos especialmente por seu gênero, raça, religião, nacionalidade, orientação sexual, entre outros. $\mathrm{O}$ autor defende restrições legais aos discursos de ódio, apoiando uma espécie de regulamentação proibidora de declarações públicas que possam perturbar a paz social ou atacar diretamente membros de minorias vulneráveis. Diversos países, tais como Alemanha, Nova Zelândia, Canadá, Dinamarca e Reino Unido, segundo o autor, já adotaram algum tipo de regulação, ou leis, proibindo declarações públicas como aquelas que:

\footnotetext{
1 Tradução livre dos autores. 
[...] incitam o "ódio contra qualquer grupo identificável em que tal incitação é suscetível de conduzir a uma violação da paz social" (Canadá); "ou declarações pelas quais um grupo de pessoas é ameaçado, ridicularizado ou degradado em razão de sua raça, cor da pele, nacionalidade ou etnia" (Dinamarca); ou ataques à "dignidade humana de outros por insultar, difamar maliciosamente ou difamar segmentos da população" (Alemanha); ou "palavras ameaçadoras, abusivas ou insultantes ... que possam excitar hostilidade contra ou reduzir à ignomínia qualquer grupo de pessoas...com fundamento na cor, na raça ou étnica, ou em origens étnicas ou nacionais de um grupo de pessoas" (Nova Zelândia); ou o uso de "palavras ameaçadoras, abusivas ou insultantes ou comportamentos, quando destinam-se a incitar ódio racial," ou quando "considerando todas as circunstâncias o ódio racial é capaz de causar agitações desse modo" (Reino Unido) (WALDRON, 2012, p. 8).

A característica definidora do discurso do ódio, segundo Waldron, é a sua capacidade para infringir a dignidade humana, não entendida em termos absolutos, mas como um status social especial que deve ser reafirmado pela lei. Assim, a dignidade é traduzida como o reconhecimento que toda pessoa pode - e deve - exigir a seus concidadãos de sua condição de individuo apto à vida em sociedade. O conceito de dignidade, neste sentido, diz respeito ao modo pelo qual uma pessoa é recebida em sociedade, situação que vai além dos requisitos formais de cidadania - direitos políticos, passaporte, entre outros. A dignidade está associada à reputação de uma pessoa na sociedade (WALDRON, 2012, p. 138-143).

Waldron afirma que o discurso difamatório adotado contra um grupo ou uma coletividade, por minar a dignidade de seus membros, deve ser proibido por lei. A difamação mina o status social do indivíduo, diminuindo sua condição humana perante a maioria da sociedade em que vive e, consequentemente, sua aceitação. Assim, para o autor, cabe à política assegurar, por meio do direito, a proteção da "dignidade das pessoas e seu tratamento decente na sociedade" (2012, p. 107). Ainda segundo Waldron,

\footnotetext{
Individualmente ou em grupo, esses ataques contra a reputação equivalem a um assalto contra a dignidade das pessoas. Dignidade entendida como condição social básica dos indivíduos, reconhecimento de sua igualdade social e do seu status de portadores de direitos humanos e constitucionais (WALDRON, 2010, p. 1610).
}

Com respeito aos efeitos do discurso de ódio, Waldron adota como parâmetro de avaliação o conceito formulado por John Rawls de "sociedade bem ordenada" (well ordered society), isto é, aquela na qual todos os seus membros aceitam os mesmos princípios de justiça. Este é um ideal a ser perseguido por toda sociedade autenticamente democrática. Conceitualmente, a sociedade bem ordenada deve adotar um compromisso geral com os princípios de justiça e dignidade, devido a todos os membros da sociedade. Assim, "uma REU, Sorocaba, SP, v. 43, n. 1, p. 209 - 225, jun. 2017 
sociedade não pode ser bem-ordenada se pessoas defendem o ódio racial ou religioso, haja vista a ideia de uma sociedade bem-ordenada ser aquela amplamente e efetivamente governada por uma concepção de justiça” (WALDRON, 2012, p. 77-78).

Consequentemente, tudo que afete a forma como a sociedade se apresenta ante seus cidadãos, e que coloque em risco o compromisso da sociedade com a dignidade destes deve ser censurado. Neste sentido, observa-se que o discurso do ódio não é apenas um conjunto de ideias que flui para o debate público, mas constitui uma atividade que define o ambiente social, tornando mais difícil a integração das minorias na sociedade. Assim, entende-se que a forma que uma sociedade se apresenta publicamente constitui o principal modo de transmitir segurança a seus membros. O discurso de ódio atenta frontalmente essa confiança, em particular, atenta contra a ideia de justiça e dignidade na sociedade, ignorando que a dignidade é inerente a condição humana.

Para o autor, o discurso de ódio lesiona a dignidade dos indivíduos pertencentes aos grupos difamados, desfigurando a aparência da sociedade como coletividade comprometida com os mais básicos princípios de justiça, distanciando do ideal de sociedade bem ordenada. $\mathrm{O}$ discurso de ódio desfigura as sociedades, tornando-as hostis aos membros das minorias e grupos atacados.

Aqueles que emitem, publicam ou postam expressões de ódio contra uma minoria estão contribuindo para o aumento da violência na sociedade. Mesmo que um discurso de ódio isolado possa não parecer tão significante, ele é um ataque geral e difuso e, em alguns casos, até mesmo implícito. Nesse sentido, Waldron tem o grande mérito de retirar a atenção de quem está proferindo o discurso para quem está sendo vítima do discurso.

O principal argumento contra a criminalização do discurso de ódio é a defesa da liberdade de expressão. Entende-se que a restrição a qualquer liberdade é motivo de discussão (e deve ser), e nesse sentido a discussão acerca da liberdade de expressão remete à própria noção de democracia. Dessa forma, a posição contrária a promulgação de leis que criminalizam o discurso de ódio, utiliza o argumento que isso pode comprometer o próprio processo democrático. O filósofo do direito americano, Ronald Dworkin é um dos principais defensores desse argumento.

Dworkin (2009) entende que a liberdade de expressão é um direito universal e irrestrito (ou quase irrestrito), sendo parte constitutiva democracia. Assim, o princípio básico que dá 
suporte à liberdade de expressão como um direito humano universal é a exigência de que todos devem ser tratados com igual consideração e respeito, ou seja, a aceitação da condição da dignidade humana.

Embora os processos majoritários sejam condição necessária à legitimidade política, uma democracia justa, segundo Dworkin, deve ter o que ele denomina de democratic background. Dessa forma, a decisão da maioria somente será justa quando todos tenham oportunidade de expressar suas opiniões, medos ou gostos ou mesmo preconceitos. O autor entende que, ao estabelecer restrições à liberdade de expressão, como vedações aos discursos de ódio, o Estado deixaria de respeitar o status de cada indivíduo como membro livre e igual da comunidade política. Assim, a democracia deve buscar a legitimidade através de processos majoritários, mas também garantir o direito de cada cidadão de participar no processo pelos quais decisões coletivas são tomadas, expressando livremente sua opinião.

$\mathrm{O}$ argumento central de Dworkin relaciona o direito à liberdade de expressão com legitimidade da lei. O autor afirma que uma lei somente será legítima se for permitido um debate amplo sobre o assunto, permitindo inclusive o discurso de ódio. As restrições à liberdade de expressão nos casos de discursos de ódio é uma preocupação central para o autor, pois, tais restrições podem ser utilizadas por maiorias legislativas ou pelo próprio governo no intuito de calar vozes contrárias aos seus ideais ou interesses (2009, p. ix).

Para o autor, em uma democracia “[...] ninguém, por mais poderoso ou impotente que seja, pode ter o direito de não ser insultado ou ofendido" (2009, p. viii). Sendo esse um argumento importante para aqueles que defendem a liberdade de expressão. Em uma sociedade democrática, que garante a liberdade de expressão como um direito fundamental, os indivíduos devem debater questões de relevância pública sem nenhum tipo de exclusão. Ninguém pode ser excluído de participar de um debate público porque outrem possa sentir-se ofendido com suas ideias. Não é possível receber somente ideias favoráveis, mas também aquelas que chocam, ofendem e perturbam. De acordo com os defensores da liberdade de expressão, nas democracias modernas e pluralistas seria praticamente impossível realizar debates públicos sem de alguma forma chocar, ofender ou perturbar alguém.

No contexto brasileiro, a liberdade de expressão - assegurada pela Constituição Federal (Art.5) - compreende a manifestação da opinião, pensamentos e ideia sem receio de censura, sendo reconhecido como um direito de qualquer indivíduo. Porém, proporcionalmente à 
ampliação de suas liberdades aumentam também as reponsabilidades, exigindo cuidado com o que pode ou deve ser falado ou divulgado. A liberdade de expressão não pode sobrepor o direito alheio, nem macular a imagem ou dignidade de outrem.

\section{Discurso de ódio na tribuna da Câmara de Deputados do Brasil}

No dia 09 de dezembro de 2014, na tribuna da Câmara dos Deputados, o deputado federal Jair Bolsonaro repete o insulto à deputada Maria do Rosário: "só não te estupro porque você não merece"2. Em 2003, durante uma entrevista à Rede TV!, Jair Bolsonaro discutiu com a deputada: "O senhor promove a violência", disse Maria do Rosário na ocasião, e Bolsonaro respondeu: "Eu sou estuprador agora? Jamais iria estuprar você, porque você não merece". Além disso, empurrou e chamou a deputada de "vagabunda".

Em 11 de dezembro de 2014, a Associação dos Juízes para a Democracia - AJD - emitiu uma nota de repúdio ao pronunciamento do deputado federal Jair Messias Bolsonaro. Para os representantes da $\mathrm{AJD}$, a fala do parlamentar, sugerindo uma distinção entre "mulheres que merecem" e outras que "não merecem" ser estupradas, ultrapassa os limites da discussão política protegida pela imunidade parlamentar e expõe um claro discurso de ódio, atingindo, de modo geral, todas as mulheres brasileiras. Esse tipo de discurso coloca em risco conquistas obtidas pelos movimentos feministas e pela sociedade como um todo, revelando a necessidade de luta diária contra a misoginia ${ }^{3}$ e o sexismo ${ }^{4}$. De acordo com a Associação,

\footnotetext{
${ }^{2}$ Amplamente divulgada nos meios de comunicação e nas redes sociais.

${ }^{3}$ Misoginia é o ódio, desprezo ou preconceito contra mulheres. Pode se manifestar de várias maneiras, incluindo a exclusão social, a discriminação sexual, hostilidade, androcentrismo, o patriarcado, ideias de privilégio masculino, a depreciação das mulheres, violência contra as mulheres e objetificação sexual. ${ }^{4}$ Sexismo é o preconceito ou discriminação baseada no sexo ou gênero de uma pessoa. O sexismo extremo pode
fomentar o assédio sexual, estupro e outras formas de violência sexual.
} 
[...] basta verificar que, segundo estudo divulgado pelo IPEA, estima-se que 527 mil pessoas são estupradas anualmente no Brasil, sendo $89 \%$ das vítimas do sexo feminino, e que, de acordo com dados do Fórum Brasileiro de Segurança Pública, a cada 12 segundos uma mulher sofre algum tipo de violência no país, dados que revelam a sobrevivência de uma cultura arcaica e retrógrada que coloca a mulher em posição de submissão com relação aos homens, lógica que encontra no abuso sexual a sua mais infausta expressão (BEZERRA; BERNARDES; MARTINS, 2016, p. 1).

O pronunciamento do deputado Jair Bolsonaro despreza a longa luta travada no seio da sociedade brasileira para superar esse odioso caldo cultural que naturaliza o estupro. Pior, utiliza os holofotes de uma tribuna parlamentar para reavivar e reforçar o discurso machista de violência contra as mulheres. Segundo a Associação,

[...] em nenhuma circunstância e sob nenhum pretexto, de forma expressa ou velada, irônica ou não, em retorsão à ofensa anterior ou não, é dado a qualquer pessoa sobretudo ao titular de um mandato eletivo - nem sequer dar a entender que uma mulher, por qualquer motivo seja, mereça ter sua liberdade sexual violada (BEZERRA; BERNARDES; MARTINS, 2016, p. 1).

A AJD lembra, ainda, que num pronunciamento o parlamentar não fala apenas por si e seus eleitores, mas por toda a sociedade brasileira. De maneira alguma, alertam os juízes, esse discurso:

[...] pode contrastar os fundamentos e objetivos da República, valores imprescindíveis a um Estado Democrático de Direito, tais como a dignidade da pessoa humana (artigo 2. ${ }^{\circ}$, III, da Constituição) e a erradicação de preconceitos de origem, raça, sexo, cor, idade e quaisquer outras formas de discriminação (artigo $3^{\circ}$, IV, da Constituição), notadamente aqueles que impliquem ataques discriminatórios a setores sociais historicamente vulneráveis (BEZERRA; BERNARDES; MARTINS, 2016, p. 1).

A imunidade material dos congressistas por suas opiniões e palavras, afirmam os magistrados, não pode ser utilizada como salvaguarda a práticas que atentam contra valores caros ao Estado Democrático de Direito. Essa "garantia" obtida com a imunidade parlamentar não é ilimitada, sendo submetida aos limites do decoro parlamentar 5 .

Ao final da nota, a entidade clama pela apuração de quebra de decoro parlamentar pelas instâncias competentes, e também manifesta sua repulsa ao sexismo e a qualquer forma de discriminação. Contra o aviltamento da dignidade das mulheres pela manifestação parlamentar,

\footnotetext{
${ }^{5}$ Decoro parlamentar é a conduta individual exemplar que se espera ser adotada pelos políticos, representantes eleitos de sua sociedade.
} 
a AJD reforça seu posicionamento de integral solidariedade e respeito às mulheres, e coloca-se como aliada nas lutas pelo empoderamento e isonomia do gênero feminino.

Em junho de 2016, o Supremo Tribunal Federal - STF - aceitou denúncia e tornou réu o deputado Jair Bolsonaro (PSC-RJ) por injúria e incitação pública ao estupro. De acordo com o relator do caso, ministro Luiz Fux, Bolsonaro não pode ser protegido pela prerrogativa de imunidade parlamentar, pois o que ele disse não tem nenhuma relação com sua atividade na Câmara.

\section{Discurso, política e ódio}

Entende-se que o discurso é o lugar de reprodução dos discursos das classes e das frações de classe. Assim, as visões de mundo se materializam na linguagem em suas diferentes manifestações: a verbal, a visual, a gestual, etc. A maneira de pensar o mundo, numa dada época, subordina-se aos temas e figuras estabelecidos por essas visões de mundo. Para Charaudeau (2011), a política é um verdadeiro campo de batalha em que se trava uma guerra simbólica, visando estabelecer relações de dominação ou pactos de convenção. O discurso político objetiva, assim, influenciar as opiniões a fim de obter adesões às propostas que defende, ou rejeições aos projetos adversários.

\footnotetext{
O discurso político não esgota, de forma alguma, todo o conceito político, mas não há política sem discurso. Este é constitutivo daquela. A linguagem é o que motiva a ação, a orienta e lhe dá sentido. A política depende da ação e se inscreve constitutivamente nas relações de influência social, e a linguagem, em virtude do fenômeno de circulação dos discursos, é o que permite que se constituam espaços de discussão, de persuasão e de sedução nos quais se elaboram o pensamento e a ação políticos. A ação política e o discurso político estão indissociavelmente ligados, o que justifica pelo mesmo raciocínio o estudo político pelo discurso (CHARAUDEAU, 2011, p. 39).
}

A Análise de Discurso (doravante $\mathrm{AD}$ ) propõe várias metodologias para desvelar regularidades e os mecanismos por meio dos quais se produzem e se interpretam a fala (escrita ou oral) em situações de comunicação. Os métodos da AD têm proporcionado o desvelamento de uma série de relações hegemônicas não aparentes nas manifestações comunicativas, mas que são passíveis de se apreender na dimensão discursiva.

Parte-se do princípio, que a $\mathrm{AD}$ tem como propósito "[...] a compreensão de como um objeto simbólico produz sentidos, como ele está investido de significância para e por sujeitos". 
Essa compreensão, ainda segundo a autora, "implica em explicitar como o texto organiza os gestos de interpretação que relacionam sujeito e sentido. Produzem-se assim novas práticas de leitura" (ORLANDI, 2010, 26-27).

Importante noção no âmbito da análise do discurso, as condições de produção (doravante CP) trazem para o discurso os lugares sociais e suas representações, e também as relações de força e as relações de mundo da sociedade, independente da dimensão contextual estrita ou ampla 6 .

$\mathrm{O}$ contexto imediato da enunciação do discurso analisado - $\mathrm{CP}$ em sentido estrito refere-se ao discurso do deputado Jair Bolsonaro proferido em dezembro de 2014. Entretanto, essa "disputa" entre os dois deputados iniciou-se em 2003, logo após o trágico caso Liana Friedenbach - a jovem de dezesseis anos que foi estuprada e morta. Um dos criminosos, menor de idade, cumpriu pena alternativa, e provocou a revolta de parte da opinião pública brasileira na época. No período de maior exposição do caso Liana na mídia, Bolsonaro aproveitou para divulgar uma de suas antigas bandeiras políticas: a defesa da redução da maioridade penal, algo totalmente repudiado por Maria do Rosário e demais políticos defensores dos Direitos Humanos. Bolsonaro dava uma entrevista no Salão Verde da Câmara de Deputados, quando foi interpelado por Maria do Rosário, dizendo que seu discurso de ódio incitava a violência. Bolsonaro revidou com deboche, ironias e agressões verbais, entre elas a frase: "só não te estupro porque você não merece". A frase foi retomada na tribuna da Câmara de Deputados onze anos mais tarde, em 2014, durante mais um embate entre os deputados.

Já as CP em sentido amplo abrangem, além do contexto sócio-histórico, também do imaginário produzido pelas instituições, sobre o já-dito, sobre a memória. Dessa forma, a discussão sobre o discurso de Bolsonaro passa pelo debate sobre a relação da desigualdade cultural e política entre homens e mulheres, e também pela cultura do estupro, uma violência

\footnotetext{
${ }^{6}$ Como afirma Brandão, as CP “constituem a instância verbal de produção do discurso, o contexto histórico-social, os interlocutores, o lugar de onde falam e a imagem que fazem de si, do outro e do referente" (2004, p. 105). Conforme Orlandi, o sentido estrito das CP refere-se ao contexto imediato da enunciação, enquanto o sentido amplo inclui os contextos sócio-histórico e ideológico. As CP em sentido amplo abrangem, além do contexto sócio-histórico, também do imaginário produzido pelas instituições, sobre o já-dito, sobre a memória. Para Orlandi, essa "memória do dizer" refere-se ao interdiscurso, ou seja, ao exterior constitutivo do discurso: "O interdiscurso é todo o conjunto de formulações feitas e já esquecidas que determinam o que dizemos. Para que minhas palavras tenham sentido é preciso que elas já façam sentido. E isto é efeito do interdiscurso: é preciso que o que foi dito por um sujeito específico, em um momento particular se apague na memória para que, passando para o 'anonimato', possa fazer sentido em 'minhas' palavras” (2010, p. 33-34).
} 
que ainda persiste no século XXI a despeito das sucessivas transformações políticas, econômicas e sociais.

Ao proferir seu voto pela aceitação da denúncia contra o deputado, o ministro do STF, Luís Roberto Barroso, afirmou que declarações como a de Bolsonaro contribuem para consolidar a cultura do estupro no Brasil: "Afirmar que não estupraria uma mulher porque ela não merece é uma ofensa à pessoa atacada, mas uma ofensa à condição feminina" (AGUIAR; PERON, 2016, p. 1).

Importante dizer que a cultura do estupro tem estreita relação com a herança do machismo, que não reconhece a mulher em igualdade de condições,

O estupro, que é uma das formas mais graves de violência, que atinge especialmente mulheres de quaisquer idades, raça ou etnia, classe social e orientação sexual, sempre provoca indignação geral. Mas em certos contextos, não é percebido com tal gravidade por seus autores, que atribuem a culpa à mulher, que teria dado motivos para a liberação desse impulso (RODRIGUES, 2016, p. 44).

A memória coletiva também é acionada pelo discurso do parlamentar ao referenciar a perspectiva da superioridade masculina em relação às mulheres num país que ainda guarda resquícios de uma sociedade patriarcal. Mesmo com todo esforço para mudar essa situação, segundo Rodrigues (2016, p. 44), “[...] posicionamentos excludentes ainda podem ser observados nas várias sociedades, como traços de uma herança cultural enraizada que pressupõe a inferioridade feminina, o que tem origem em concepções religiosas e biológicas".

Os dizeres não são apenas mensagens passíveis de decodificação, mas efeitos de sentidos produzidos em condições determinadas, e que deixam vestígios no modo como se diz,

\footnotetext{
São pistas que ele aprende a seguir para compreender os sentidos aí produzidos, pondo em relação o dizer com sua exterioridade, suas condições de produção. Esses sentidos têm a ver com o que é dito ali, mas também em outros lugares, assim como com o que não é dito, e com o que poderia ser dito e não foi. Desse modo, as margens do dizer, do texto, também fazem parte dele (ORLANDI, 2010, p. 30).
}

Por outro lado, os sentidos também são produzidos a partir da memória, da história. Assim, o não-dito na sequência discursiva aqui analisada remete a perspectiva da superioridade masculina em relação às mulheres. Quando o deputado diz que a deputada não merece ser estuprada - insinua que "ela é muito feia" e "não faz meu gênero" -, diz sublinarmente que 
algumas mulheres merecem, ou, numa perspectiva ainda mais grave, que ele é potencial estuprador.

Nas margens do texto é possível identificar um indício de uma pretensa superioridade biológica masculina, tornando a vítima "merecedora" de tal violência, sendo que essa reflexão perpassa vários aspectos da vida quotidiana. "Assim, Bolsonaro, como homem, se atribuiu o papel de julgar quando e os motivos pelos quais uma mulher poderia ou não ser estuprada [...]" (RODRIGUES, 2016, p. 47).

A constituição dos sentidos e dos sujeitos do discurso se dá em processos, onde coexistem os jogos simbólicos - o que não temos o controle - e o equívoco, por meio do trabalho da ideologia e do inconsciente. Dessa maneira, pode-se afirmar que as visões de mundo se materializam na linguagem em suas diferentes manifestações: a verbal, a visual, a gestual. Assim, a manifestação espontânea e agressiva de Bolsonaro revela a provável herança sexista que interferiu na sua formação.

\section{Discurso, mídia e espetáculo}

Na sociedade contemporânea, o conhecimento constitui-se, preferencialmente, a partir da recepção das formas simbólicas veiculadas pela mídia. A prevalência das tecnologias de comunicação e a facilidade de acesso à informação afetam a vida no espaço público, conferindo cada vez mais importância à mídia.

A mídia deve ser analisada nesta diversidade de possibilidades: informando e formando a opinião pública. As representações construídas pela mídia tornaram-se fundamentais nas experiências individuais e sociais na contemporaneidade (CHAIA, 2004, p. 23).

O que é veiculado no discurso da mídia tem a capacidade de influenciar coletividades, ou parte dessas. O rumor ${ }^{7}$ propagado pela mídia tende a aumentar a sensação de insegurança, favorecendo a emergência de comportamentos agressivos que escapam ao controle crítico.

\footnotetext{
${ }^{7}$ De acordo com Delumeau, "Um rumor nasce, portanto, sobre um prévio de inquietações acumuladas e resulta de uma preparação mental criada pela convergência de várias ameaças ou de diversos infortúnios que somam seus efeitos" (2009, p. 269).
} 
Para atingir seus objetivos e causar dano, o discurso de ódio precisa ser veiculado por um meio comunicacional que, dependendo do poder difusor do veículo, pode ser menos ou mais nocivo. Embora a evolução dos meios de comunicação e das tecnologias da informação propicie intenso intercâmbio entre as pessoas, democratizando a informação, por outro lado, também potencializa o alcance dos conteúdos perniciosos, como o discurso de ódio, como lembra Ezequiel, "A mídia, como produtora de informações, coloca-se como fonte geradora de sistemas de representação da realidade, utilizada para compreender a sociedade" $(2015$, p. 118).

De acordo com Debord ${ }^{8}$ (2004), no plano das técnicas, a imagem "construída" pode se tornar a principal ligação do indivíduo com o mundo real, que ele vivenciava por si mesmo. Na sociedade espetacular não há mais espaço para vivermos nossas próprias experiências, são os modelos que vivem em nosso lugar: "tudo o que era vivido diretamente torna-se uma representação" (DEBORD, 2004, p. 13).

Os meios de comunicação, na chamada sociedade da informação, representam um campo privilegiado na disputa pela hegemonia, segundo Coelho (2006, p. 18), “o triunfo da sociedade do espetáculo corresponde a monopolização da aparência pela classe dominante e seus funcionários (os que pensam/agem a seu serviço)”.

O discurso de Bolsonaro repercutiu amplamente na grande mídia e gerou debates acalorados nas redes sociais. Mesmo descontando as posições mais agressivas dos seguidores dos protagonistas, ocorreu uma avalanche de comentários equivocados, evidenciando ignorância sobre o contexto que envolveu o assunto. $\mathrm{O}$ advento das tecnologias da informação potencializa a notícia e também seus desdobramentos. Dessa forma, entende-se que o discurso de Bolsonaro teve grande potencial para estimular o debate público, repercutindo nas redes sociais as mensagens de seguidores que reiteraram o discurso de ódio.

Os diversos comentários e opiniões que surgiram após o discurso de Bolsonaro mostraram um desvio de atenção do problema real, além da espetacularização do caso. Mesmo entre aqueles que criticaram duramente a posição do deputado, não se questionaram de onde ela surgiu, qual a raiz desse discurso.

\footnotetext{
${ }^{8}$ Os fundamentos da crítica de Debord são a vida cotidiana e a generalização do fetichismo da mercadoria, que invadiu todos os espaços da vida em sociedade. A mercantilização de tudo produz o espetáculo ininterrupto. Nele, o tempo, o espaço, o lazer, a comunicação, a cultura e tudo o mais é perpassado pela alienação. Para Debord, "O espetáculo não é um conjunto de imagens, mas uma relação social entre pessoas, mediada por imagens" (2004, p. 14).
} 
Deram muita publicidade para o deputado por ele ser uma figura pública, mas se fosse qualquer outro cidadão que declarasse tais atrocidades, tudo estaria em paz. Outra parcela da população fez uma marcha a favor de Bolsonaro na Avenida Paulista. Essa não merece nem grandes palavras, só reafirma a mentalidade retrógrada de grande parcela da população. Será que não é hora de revermos os valores que colocamos no poder? É realmente este tipo de país intolerante que sempre quisemos construir? (ARBEX JR., 2011, p. 1).

No atual cenário político brasileiro, em que o reconhecimento dos direitos fundamentais está no centro das reivindicações, os discursos de ódio espetacularizados na mídia geram representações sociais, nas quais é possível identificar formas de discriminação e preconceito. Além disso, o debate político espetacularizado na mídia transborda nas redes sociais, palco de disputas ideológicas vazias de argumentação e de pouca consistência, onde sobram agressões, xingamentos e ódio. Dessa forma, o princípio básico da diferença, que permite mesclar ideologias numa sociedade heterogênea como a brasileira evapora-se, derrubando o mito de país plural e pacífico, onde a ausência de semelhança não anula a coexistência pacífica.

\section{Considerações finais}

Discursos de ódio não podem ser aceitos em nenhum modelo de sociedade moderna, principalmente numa democracia. As formas de expressão odiosas, intolerantes e retrógradas não são parte da escala de valores democráticos da sociedade ou do Estado. Este tipo de discurso, de natureza violenta é um dos riscos mais alarmantes para a democracia.

O discurso do deputado Jair Bolsonaro aqui analisado, além de expor o despreparo do deputado para lidar com situações de divergências ideológicas, também expõe o acirramento de posições políticas antagônicas na sociedade brasileira. O teor do discurso, mais do que uma discussão acalorada entre atores políticos de tendências opostas, reforça a ideia da vulnerabilidade feminina diante da imposição da força e agressividade masculina. $O$ caso expõe a mentalidade atrasada e conservadora que persiste em parte da população brasileira.

Neste artigo apresentou-se o discurso de ódio de personagem político que afronta o direito das mulheres de não serem violentadas em sua dignidade e direitos. Foram apresentadas vozes em defesa da ampla liberdade de manifestações e expressões de intolerância, em nome do direito à liberdade de expressão e da legitimidade democrática. Também foram apresentados argumentos contrários às manifestações de intolerância, defendendo restrições aos discursos e 
manifestações de ódio como necessárias e legítimas quando se objetiva proteger a dignidade dos indivíduos e, consequentemente, a própria cultura democrática.

Conclui-se que, o discurso de ódio, espetacularizado na grande mídia e nas redes sociais, fomenta a hostilidade, o preconceito e corrompe a atmosfera democrática e tolerante. Certamente, a cultura democrática encontra-se vulnerável perante a aceitação e o crescimento do ódio. É justamente pensando em evitar essa "poluição" e degradação do ambiente social, com a ascensão do ódio ao espaço público, que se entende ser necessária a aceitação de leis que proíbam os discursos de ódio.

\section{Referências}

AGUIAR, Gustavo.; PERON, Isadora. Bolsonaro vira réu por ofensa a deputada. Biblioteca do Senado Federal. Brasília: 2016 Disponível em: <https://www2.senado.leg.br/bdsf/bitstream/handle/id/523459/noticia.html?sequence=1>. Acesso em: 30 abr. 2017.

ARBEX JR., José. Editorial. Contraponto, São Paulo, n. 71, abril/2011. Disponível em: $<$ https://revistas.pucsp.br/index.php/contraponto/article/view/9749/7248>. Acesso em: 29 abr. 2017.

BEZERRA, André Augusto Salvador; BERNARDES, Célia Regina Ody; MARTINS, Dora Aparecida. Nota de repúdio à declaração sexista de parlamentar. Associação Juízes para a Democracia - AJD. 2016. Disponível em:

<http://www.ajd.org.br/documentos_ver.php?idConteudo=170>. Acesso em: 28 abr. 2017.

BRANDÃO, Helena Nagamine Introdução à análise do discurso. São Paulo: Unicamp, 2004.

CHAIA, Vera. Eleições no Brasil: o medo como estratégia política. In: RUBIM, A. A. C. (Org). Eleições presidenciais em 2002 no Brasil. São Paulo: Hacker, 2004.

CHARAUDEAU, Patrick. Discurso político. São Paulo: Contexto, 2011.

CIOCCARI, Deysi. A espetacularização política brasileira: uma análise dos políticos midiáticos eleitos para o Congresso Nacional 2015-2019. Communicare, v. 15, n. 2, p. 38$50,2015$.

COELHO, Claudio Novaes Pinto. Em torno do conceito da sociedade do espetáculo. In: COELHO, Claudio Novaes Pinto; CASTRO, Valdir de (Orgs.). Comunicação e sociedade do espetáculo. São Paulo: Paulus, 2006.

DEBORD, Guy. A sociedade do espetáculo. Rio de Janeiro: Contraponto, 2004. 
DELUMEAU, Jean. História do medo no ocidente. São Paulo: Cia. das Letras, 2009.

DWORKIN, R. Foreword. In: HARE, Ivan; WEINSTEIN, James (Orgs.). Extreme speech and democracy. Nova York: Oxford University Press, 2009.

EZEQUIEL, Vanderlei de Castro. Discurso do medo e o ódio político na disputa eleitoral brasileira de 2014. Aurora, Marília, v. 8, n. 23, p. 98-119, jun./set. 2015.

ORLANDI, Eni. Análise de discurso: princípios e procedimentos. Campinas: Pontes Editores, 2010.

RODRIGUES, Denise dos Santos. As manifestações públicas pelo combate das desigualdades culturais e políticas; evidências da cultura do estupro no século XXI. Revista Espaço

Acadêmico, Maringá, XVI, n. 183, p. 39-50, ago. 2016, Disponível em:

<http://eduem.uem.br/ojs/index.php/EspacoAcademico/article/viewFile/32863/17065>.

Acesso em: 29 abr. 2017.

SILVA, Rosane Leal. et al. Discurso do ódio em redes sociais: jurisprudência brasileira. Rev. direito GV, São Paulo, v. 7, n. 2, p. 445-467, jul./dez. 2011.

WALDRON, Jeremy. Dignity and defamation: the visibility of hate. Harvard Law Review, Cambridge, v. 123, p. 1596-1657, 2010. Disponível em: <https://harvardlawreview.org/wpcontent/uploads/pdfs/vol123_waldron.pdf> Acesso em: 05 maio 2017.

WALDRON, Jeremy. The harm in hate speech. Cambridge: Harvard University Press, 2012.

Deysi Cioccari - Pontificia Universidade Católica de São Paulo - PUC | São Paulo | São Paulo | Brasil. Contato: deysicioccari@gmail.com

Vanderlei de Castro Ezequiel - Faculdade Cásper Líbero - FCL | São Paulo | São Paulo|Brasil. Contato: vander.ce@gmail.com

Artigo recebido em maio de 2017 e aprovado em junho de 2017. 